\title{
EUROPEAN CAPITAL OF CULTURE 2023 - COMPARATIVE ANALYSIS OF THE HUNGARIAN CANDIDATE CITIES
}

\author{
Dávid FEKETE ${ }^{\mathrm{a}}$, Szabolcs MORVAY ${ }^{\mathrm{b}}$
}

a Széchenyi István University, fdavid@sze.hu

b Széchenyi István University, morvay.szabolcs@sze.hu

Cite this article: Fekete, D, Morvay, S. (2020). European Capital of Culture 2023 - Comparative Analysis of the Hungarian Candidate Cities. Deturope, 12(2), 84-104.

\begin{abstract}
A Hungarian city will be designated as the European Capital of Culture in 2023. The series of programmes are designed to show the multi-colour European culture, accordingly, the cultural values and cultural dimensions of the cities are in the focus. Several cities take part in the competition in the customary way by submitting their tender documentation within the framework of a pre-selection procedure. Györ, Veszprém and Debrecen proved to be the most probable candidate cities to win in Hungary, they were chosen to enter the second round of the selection procedure. Although the focus of intense attention usually falls on the cultural programmes planned for the project year, the period of the competition itself is also regarded an exciting phase of the project, since this is the period when candidate cities are expected to give an account of their plans, moreover, they are also expected to outline their projected development conception in the field of culture and their cultural potentials. The present study aims to analyse and confront the plans of three Hungarian cities that were selected to enter the second round of the competition and, consequently, it also intends to explore the visions, the strengths and weaknesses of the Hungarian cities of outstanding cultural ambitions mainly via factors denoted in figures. Today we know, that the winning city became Veszprém. Although based on the quantitative data we saw the other two cities as more likely to win, due to a number of qualitative as well as subjective factors, the city of Veszprém proved to be better during the selection procedure. We do not want to override the decision; we only outline an analytical framework for the cultural comparison of our culturally ambitious Hungarian cities.
\end{abstract}

Keywords: culture, European Capital of Culture, Hungarian cities, plans, competition

\begin{abstract}
2023-ban magyar város lesz Európa Kulturális Fővárosa. A programsorozat az európai kultúra sokszínüségét hivatott bemutatni, tehát középpontjában a városok kulturális értékei, kulturális dimenziói állnak. A címért mindig városok sora versenyezik pályázataikat benyújtva egy kiválasztási eljárás keretében. Győr, Veszprém és Debrecen voltak a legesélyesebb pályázók, e városok jutottak a kiválasztási eljárás második fordulójába. Bár a figyelem nagy része a projektévben szervezett kulturális programokra irányul, a pályázati fázis is izgalmas szakasza a projektnek, hiszen ekkor a pályázó városok számot adnak terveikről, a kultúra terén tervezett fejlesztési elképzeléseikről, kulturális potenciáljukról. A tanulmányban arra törekszünk, hogy a tárgyalt projekt pályázati ciklusának második fordulójába jutott három magyar város terveit ütköztessük, elemezzük, feltárva ily módon a kiemelkedő kulturális ambíciókkal bíró magyar városok kultúrával kapcsolatos vízióit, erősségeit, gyengeségeit, főképpen a számokban kifejezhető tényezők mentén. Ma már tudjuk, hogy Veszprém nyert, ugyanakkor a kvantitatív adatok alapján mi a másik két várost láttuk esélyesebbnek a győzelemre. Azonban számos kvalitatív és szubjektív tényező mentén Veszprém városa bizonyult jobbnak a kiválasztási procedúra során. Természetesen nem kívánjuk felülbírálni a döntést, csupán egy elemzési keretet kívánunk felvázolni a kulturálisan ambiciózus magyar városaink kulturális összehasonlításához.
\end{abstract}

Keywords: kultúra, Európa Kulturális Fővárosa, magyar városok, tervek, verseny 


\section{INTRODUCTION}

The urban policy of our days is integrating a new attitude into the mechanism of decisions and actions. In urban policy, there has been a more and more spreading mentality to support creativity and give priority to cultural and creative activities. The modernity of the mentality lies in the fact that formerly the settling of industrial and functional facilities was considered predominant. If Central Europe is merely taken into consideration, where the socialist urbanization model used to be prevailing during the past decades, it becomes obvious that these cities had been making great efforts to catch up with the economic development of the Western European countries basically by the aims of industrial expansion and a forced pace of developing heavy industry. (Szirmai, 1996) Western, developed countries, however, had now taken one step forward again when instead of investing in equipment and facilities they had moved towards evolving research development, innovation, human resources, and cultural economy. A characteristic feature of the period was the deterioration of outstanding industrial sectors so they had tried to compensate the process by cultural investments and by establishing research centres. (Enyedi, 2005) Recently, the issue of cultural governing has regularly been referred to in the trends of urban politics of our days. (Fekete 2018a, 2018b)

The strategy outlined above brought about excellent results later on, which could thus generate an upswing of the economic situation, the revival of urban architecture, the modern relationship between culture and tourism, and a successful shift in the structure of the regions. (Haarich \& Plaza, 2010) This was precisely the period - exactly in 1985 when the initiative of the European Capital of Culture (ECOC) project got under way, which became an incentive factor in the process of the renewal of the title-winning cities.

The competition of the Hungarian candidate cities for the European Capital of Culture title took place in the near past within the framework of which the winner city of the European Capital of Culture 2023 tender was designated. The city of Veszprém was chosen as the title owner, however, in the case of the three Hungarian cities that took part in the competition phase and the second round as well, a significant amount of inner energy, interior analyses, goals, and visions were released, which can be considered an unambiguous projection of the western type of trends in urban politics outlined above. Györ, Veszprém, and Debrecen elaborated a new cultural strategy and within the ECOC competition of these cities various cultural projects, capital investment projects, and ideas were drawn up. These cities have explored their economic potentials and also became conscious of the fact that culture and creative capital need to be considered a priority in their cities as well as in their mentality in urban politics and, besides all this, they have committed themselves to implement the targets even if, they would not win ECOC 2023 
title. Therefore it is worthwhile studying the ECOC projects in Hungary since they have comprised the main points of the cultural strategy of these cities. The main questions refer to the degree of cultural development to be expected in the cities discussed, the budget plans to be estimated for the cultural sphere in the near future and the way their cultural potential, tourism can be described, moreover, the degree of ambitions the ECOC project generated in these cities. The present study aims to find answers to the questions outlined above. The theoretical introduction of the study analyses the offered potentials of the ECOC project that are expected to strengthen the relationship between culture and city in a modern way. After that the study focuses on the characteristics of the cultural and creative economy from a perspective that these days ECOC projects have already required long-term efforts in economic development, moreover, in the application documents, the three cities have drafted commitment to strengthen this sphere. In the experimental paragraphs of the study, a supplementary research method was written concerning the three Hungarian cities, which makes it possible to make a comparative analysis of the cities according to three aspects.

\section{Culture and city}

Philip Boland notes that local actors in cities are increasingly recognizing that cultural events are an important stimulus for urban revitalization, and an excellent example of this is the European Capital of Culture project. In addition, the local culture can form a city image, and a city can be got a new brand through local culture and cultural events. (Boland, 2010) Culture is a cultural capital for cities, which is a major building element for urban development. (Wiesel, 2018) The preservation of cultural values is also important for cities, to which a cultural megaproject can make a significant contribution. (Cohen \& Shoval, 2007) At the same time, culture plays an important role in the economy. Cultural industries have become an increasingly popular area for researchers in economic geography in the last few decades. (Gibson, 2003)

The European Capital of Culture project (later ECOC) has had an impact on the relationship between culture and city in an almost revolutionary and radical way. The European initiative got under way in 1985 with a consequence of the renewal of the cities by including such elements as the modernisation of the cultural infrastructure of the cities, livening up cultural life, establishing places of employment, and the promotion of tourism. The great essentials of the ECOC program are that a dialogue of various representatives, authorities, residents, cultural institutions, politicians, private establishments, and civil institutions can be commenced. In addition, the program can 
develop in a cultural context, with a common goal for everybody which includes the development of the city and puts new life into the cultural life. The promotion of culture in the cities has become a strategic issue and the ECOC program has contributed to the process in a significant way, the idea of town development based on cultural aspects has moved in the cities. (Ooi, Hakanson, \& Lacava, 2014)

The cultural events are considered the most essential elements of the series of programs. According to Greg Richard and Robert Palmer cultural events organised in cities have become the new means of development and the revival of the cities because cultural output has become a significant element of urban economy, consumer needs in the fields of culture have been increasing, which help to improve the city image and the quality of life as well. Cultural events bring about development not only regarding culture but they also generate development as far as the society and the economy of the city is concerned. One of the key elements of the development opportunities mentioned above is the partnership between the public and private sectors and the academic sector in the process of shaping the new strategic thinking and culture-based urban development. The European capital of Culture project has provided excellent examples of this partnership phenomenon as in most of the ECOC cities a separate organisation was set up in order to implement the project and this organisation co-operated with other city operators as well. In the years to come the resulting management model could remain present in the cities that previously owned the ECOC title. (Richards \& Palmer, 2010) The economic return of the ECOC project was also manifested in providing creative impulses to the creative activities in the cities and thus creating the expansion of creative and cultural economy. (Campbell, 2011)

Over the years, the ECOC project has also become a catalyst for urban regeneration. The city of Glasgow (1990) has already consciously designed its ECOC program to accelerate the city's prosperity and increase its image. The project was successful, making Glasgow an example of such a city that took good advantage of the urban regeneration impact of a large-scale cultural event. (Garcia, 2004, Balsas, 2004) In the following years, a number of cities followed the example of Glasgow and incorporated elements of urban development into their ECOC programme, such as renewal of public spaces and certain parts of town, development of cultural infrastructure, and other infrastructural developments. Among others, Salamanca, a city in western Spain that won the title in 2002, has created a creative cultural district with new art venues, but there are also many cities - Brussels, Porto, Weimar, Genoa - that have renovated their historic center as part of their ECOC program. An example is Porto, which had a new concert hall built in 2001, 
the Casa de Música. (Balsas, 2004) The value of new cultural facilities is to give an important impetus to the cultural life of cities that can raise the levels of cultural tourism as well as cultural participation. (Richards \& Palmer, 2010)

In the context of the ECOC project, we also saw that mainly capitals as well as large cities, such as Copenhagen, tried to improve their own position in terms of tourism and global city rankings. (Evans, 2009) These cities have recognized that the ECOC project is an excellent opportunity to explore issues related to cultural tourism, also because the project involves a multitude of cultural events. The cities can address a number of issues in the framework of the ECOC project, for example, improving the city picture, accelerating urban regeneration, promoting cultural supply, developing partnerships, all of which are related to cultural tourism. In this context, of course, we can talk about longterm sustainable results if cultural regeneration initiatives exist as part of the urban development strategy and if the ECOC project is designed to have a harmonious relationship between cultural demand, the economy, locals, and tourists. (Palmer \& Rae, 2004)

Since 2007, cities in Central and Eastern Europe have also been classified as cities that own the ECOC title (Fig. 1). Nine cities, including Pécs as a Hungarian city, implemented the ECOC program. The European Capitals of Culture project in Central and Eastern Europe has also demonstrated the ability of the project to renew the relationship of culture and city in a revolutionary way. In the macro-region of Hungary, the period of nine ECOC years brought to the surface various elements of urban renewal among others the development of urban infrastructure, modernization, the establishment of new cultural sites and facilities as well as the utilisation of industrial sites and buildings for cultural purposes. Spatial cultural networks developed as the ECOC cities organised cultural programs with partner settlements in their region. In many cities derelict districts were successfully reconstructed and integrated in the bustling city life. These quarters of the cities were often given a unique image and special characteristics and new cultural features were also added to their wealth. In the course of the projects the cities did not forget about of the disadvantaged groups of the society either. They aimed at better social integration of these groups through cultural communication. Every city became known by their ECOC projects on an international, European scale. Millions of tourists and visitors came to these cities in the program years. (Morvay, Rechnitzer, \& Fekete, 2020) 
Figure 1 European Capitals of Culture in Central and Estern Europe

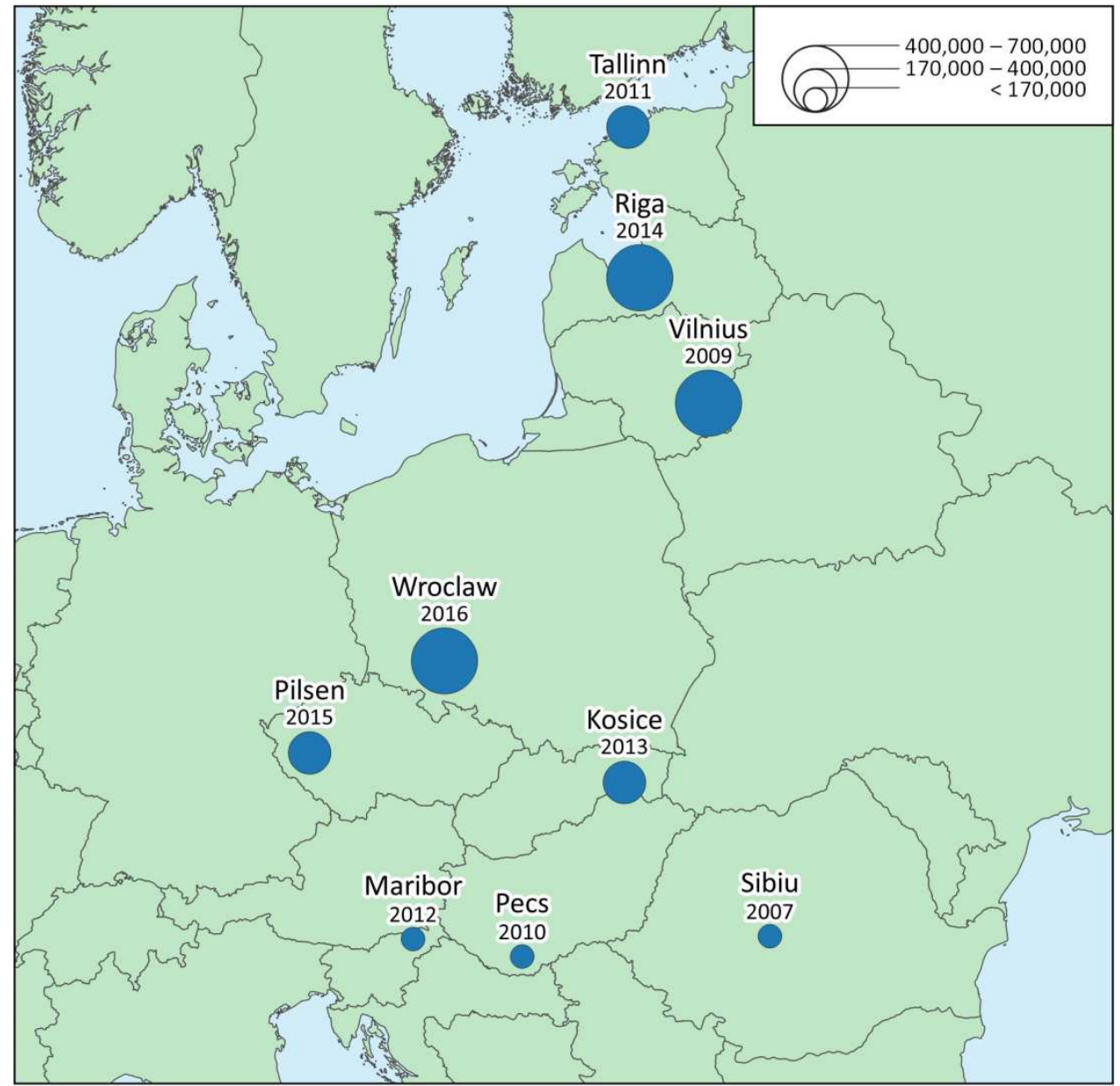

Source: own design

\section{Cultural and creative economy}

Over the past decades, the ECOC initiative has been complemented by the tendency of economic development in addition to cultural events and programs. Cultural economy and the creative economy are considered a segment within the economy for which the ECOC project can provide impulses and support mechanisms since the winning city, as a capital of culture, can evolve its creative and cultural potentials during the series of events. In the last two decades, urban leaders and city-research professionals have been confronted with very specific characteristics of the creative and cultural economy itself, because in many cases, as a new alternative, the old, usually disrupted industry has been replaced by activities of the cultural and creative industry and, as a matter of fact, substituted for former industrial sectors. The cultural and creative industry generate new innovative products and services but it provides valuable input for other industries as well. Creativity can now be regarded as one of the most important pillars of the new economy but it should be emphasized that art and culture have started to represent new 
economic potential. The concept of the creative economy cannot be defined precisely because creativity by itself is a difficult idea to grasp and creativity can be found in all areas of human activity. Consequently, areas like cultural, scientific, technological, and economic creativity can be formed. In fact, as far as the individual is concerned, categories like emotional, cognitive, intentional, and spontaneous creativity can also be distinguished. (Hojnik \& Rebernik, 2014)

Research on the creative economy has been intensifying lately and this can be explained by the fact that the role of creative industry has become more significant during the latter decade and it is becoming an increasingly important segment of the economic systems. Several reports have been drafted at international, national and regional level and these reports show that creative industry has had a significant influence on regional and macroeconomic issues. Examples include the KEA European Affairs 2006 publication, the 2007 UNESCO report, the 2008 European Parliament publication or the 2010 UNCTAD report.

The definition of creative economy was also given by the European Union in the Green Paper published in 2010 according to which creative economy involves industrial sectors in which culture represents the input factors and it has a cultural dimension, yet the output factors are functional like architecture, design, graphic design or advertising. Apart from the notion of the creative economy, the concept of cultural industry gains significance as well when the production and "distribution" of the products and services of industries are discussed which have a specific character. The process of production and consumption takes place at the same time, embodying and expressing the cultural expression independently of any commercial value. These fields include performing arts, visual arts, cultural heritage, films, books, and media. (Green Paper, 2010)

The international organization UNCTAD also provides a concept, however, it refers to a very broad category. According to the definition creative industry is regarded to be a certain set of the production of services and products, manufacturing and distribution in which processes creativity and intellectual capital represent the prime input factor. This includes a range of knowledge-based activities, focusing not only on arts, and is able to generate revenue through trade and proprietorship, includes tangible products and nontangible intellectual or artistic services with creative content, economic value, and market intent. It is at the crossroads of arts, service, and industry sectors and represents a new dynamic sector in world trade (UNCTAD, 2010) 
Apart from the effects that the creative economy has had on regional and macroeconomy, it has also been interpreted as a certain kind of social ecology. The reason for this is that the creative economy can attract high qualified workforce into the regions. At the same time, it also attracts investment and generates new business activities like restaurants, clubs, theatre performances, art galleries, and various other potentials to develop cultural life. The creative industry is also the means of the circulation of information, it is able to initiate communication and create entertainment facilities, moreover, it can be considered a key factor in the process of the approach of the economy to the cultural environment. (Deuze, 2009)

Various models have been drawn up to make the concept of the creative industry comprehensible. The most frequently used model is the UK DSMS model - the symbolic text model - which contains the core branches of cultural industry, the peripheral branches of cultural industry, and the branches of cultural industry that are on the dividing line. However, the model of homocentric circles can also be mentioned (core creative arts, other core branches of the creative industry, broader branches of cultural industry, and related industrial branches) as well as the WIPO model of copyrights in all countries (core copyright industries, dependent copyright industries, and partial copyright industries). It is not an easy task to compare the models outlined above as creative industries are interpreted in various ways by the individual models and the statistical figures and data of the organisations concerning the creative industry of a particular country are not compatible with one another. (Throsby, 2010)

Nevertheless, in consequence of the increasing interest shown in the creative industry researchers are making great efforts to make an adequate index that is suitable to compare different countries. One of such endeavours can be represented by the European Index of Creativity, which tries to integrate the indicators related to culture-based creativity, or rather it aims to incorporate the existing social-economic indicator scheme, like for instance the European Innovation Scoreboard. The cultural dimensions of creativity require factors that other indices do not include. The followings can be brought as examples: education in art schools, the rate of employment in the field of culture, the supply of cultural events, the rate of participation in cultural events, examples of technological breakthrough, the support of creative activities regarding regulation and financing and the contribution of creative industry to the economy. There are approximately 32 indicators of this kind in the European Index of Creativity. These indicators are assorted in five pillars of creativity: human capital, technology, institutional environment, social environment, openness and diversity. (Hojnik \& Rebernik, 2014) 


\section{METHODOLOGY AND DATA}

The focus of the present study is the comparative analysis of three Hungarian candidate cities that got into the second round of the competition to win the European Capital of Culture title. In 2023 Hungary will be the exclusive representative of the European Capital of Culture programme as the cities of the other pre-selected country (UK) could not participate in the selection process because of Brexit. Accordingly, the present analysis endeavours to compare Györ, Veszprém and Debrecen according to the given indicators. As a database the statistics and data releases of the second round of the three cities were used primarily supplemented by data from the Central Statistics Office related databases.

The present study does not aim to compare the cultural value of the three application dossiers, much rather would it intend to set up gradation on the basis of measurable, quantitative data.

The data sets available in the applications were arranged into groups, so three indicator groups were formed in the Tab. 1 according to three aspects: cultural capacity, tourism potential and financial capacity. 14 indicators were assigned for these three groups in order to justify the quantitative comparative analysis of the present study. It must be emphasized that the aspects of the selection process were not naturally confined to these fields, various qualitative and, in many cases, subjective factors had their role in the process as well (ability to implement, European dimension, cultural content etc.), which are not included in the research, but which certainly had an influence on the jury.

Table 1 Research factors and related indicators

\begin{tabular}{|l|l|}
\hline Criterion & Indicators \\
\hline \multirow{5}{*}{ Cultural capacity } & I1. Number of institutions of public education \\
\cline { 2 - 2 } & I2. Number of cultural programmes \\
\cline { 2 - 2 } & I3. Number of participants in cultural programmes \\
\cline { 2 - 3 } Tourism potentials & I4. Number of institutions of historical heritage \\
\hline & I5. Number of museum exhibitions \\
\hline \multirow{5}{*}{ Financial capacities } & I6. Number of museum visitors \\
\hline & I1. Number of theatre performances \\
\hline & I1. Number of spectators at the theatres \\
\hline & I11. Volume of cultural budget \\
\hline & I13. Number of planned investments \\
\hline & I14. Planned amount of operating costs \\
\hline
\end{tabular}

Source: own editing 


\section{THE CAPACITIES OF THE CANDIDATE}

The three applicant cities have different capacities concerning the fields of culture, tourism and the strength of their economy. These capacities can be denoted in figures, they are set data that appear in the tender dossiers of each city or and other parameters are also determinant in various aspects of the execution of the program like for example the number of settlements in the surroundings of the city, the number of residents in the applicant city or the capacity of their institutions.

In the analysis of national competitors, it is important to take into consideration the number and size of the settlements that surround the central city. Holders of earlier ECOC organised programmes one after the other together with partner settlements, consequently, the volume of the conurbation is a determinant factor. Tab. 2 makes it evident that only the Györ region is real conurbation, the number of settlements of which is 68 . However, the competitor cities are centres for settlements of a big city, the Debrecen group of settlements has 13 settlements and the Veszprém group has 18 settlements. The table also contains figures regarding the number of population of these cities, Debrecen is the second most populated city of Hungary with 203.000 inhabitants, Györ has approximately 130.000 inhabitants and Veszprém has 60.000 inhabitants.

Table 2 Number of settlements in the economic attraction zone and the number of inhabitants in the applicant cities (data of 2014)

\begin{tabular}{|c|c|c|}
\hline Types of spatial structures & $\begin{array}{l}\text { Number of } \\
\text { settlements }\end{array}$ & Population \\
\hline Conurbation & & \\
\hline of Györ & 68 & 129.568 \\
\hline Györ & & \\
\hline Settlement groups of a big city & 13 & 203.059 \\
\hline of Debrecen & & 60.392 \\
\hline of Veszprém & 18 & \\
\hline Veszprém & & \\
\hline
\end{tabular}

Source: own edition based on Central Statistics Office data

\section{CULTURAL CAPACITY}

In the comparative analysis of the cultural capacities of the competitor cities the study emphasizes the capacities of the institutions of each city, the volume of cultural programmes, moreover, the number of museums and theatres and their attractive force as well. On the basis of the figures in Tab. 3, it can be told that - among the examined cities - Debrecen stands first concerning its cultural public institutions, it is the maintainer of 41 such institutions, besides, Veszprém is also a significant maintainer of public 
institutions. Győr is currently maintaining a relatively large number of cultural public institutions, but it has come third in the ranking process.

Table 3 Cultural facilities: institutions and programmes (year 2015 data)

\begin{tabular}{|c|c|c|c|c|}
\hline Candidate city & $\begin{array}{c}\text { Number of } \\
\text { cultural public } \\
\text { institutions }\end{array}$ & $\begin{array}{c}\text { Number of } \\
\text { cultural } \\
\text { programmes }\end{array}$ & $\begin{array}{c}\text { Number of } \\
\text { cultural } \\
\text { programmes } \\
\text { per capita }\end{array}$ & $\begin{array}{c}\text { Number of } \\
\text { participants in } \\
\text { cultural } \\
\text { programmes }\end{array}$ \\
\hline Györ & 25 & 1.241 & 0.010 & 336.563 \\
\hline Veszprém & 36 & 958 & 0.016 & 267.300 \\
\hline Debrecen & 41 & 5.146 & 0.025 & 727.526 \\
\hline
\end{tabular}

Own edition based on Central Statistics Office figures

Debrecen proved to be prominent concerning the number of cultural programmes as well, more than 5.000 cultural events and programmes were organised in the city. Györ can be ranked into the middle of the field, it organises 1241 programmes yearly. Finally, Veszprém comes third as the number of cultural programmes they offer is less than 1000. Nearly 728.000 people participated in the cultural events organised by Debrecen in 2015, which number represents the highest value among the competitor cities. The city of Györ comes next with a scale of approximately 300.000 . Veszprém brings up the rear with the number of 270.000 . The table also shows the number of cultural programs per capita. Based on this, it can be seen that the most programs per inhabitant were in Debrecen in the year under review, followed by Veszprém, and finally Györ closes the line. However, the indicators in this case are examined in the context of the European Capital of Culture, in which case it is not the population of the city holding the ECoC title that forms the basis of the cultural consumer base, but the number of visitors, often in the order of 1.5 million.

Table 4 Cultural facilities: museums and theatres (year 2015 data)

\begin{tabular}{|c|c|c|c|c|c|c|c|}
\hline $\begin{array}{c}\text { Candidat } \\
\text { e city }\end{array}$ & $\begin{array}{c}\text { Number } \\
\text { of } \\
\text { institutio } \\
\text { ns of } \\
\text { historical } \\
\text { heritage }\end{array}$ & $\begin{array}{c}\text { Number } \\
\text { of } \\
\text { museum } \\
\text { exhibitio } \\
\text { ns }\end{array}$ & $\begin{array}{c}\text { Numbe } \\
\text { r of } \\
\text { visitors } \\
\text { at } \\
\text { museu } \\
\mathrm{m}\end{array}$ & $\begin{array}{c}\text { Number of } \\
\text { performan } \\
\text { ce at } \\
\text { theatres }\end{array}$ & $\begin{array}{c}\text { Number of } \\
\text { performan } \\
\text { ce at } \\
\text { theatres } \\
\text { per capita }\end{array}$ & $\begin{array}{c}\text { Number } \\
\text { of } \\
\text { spectator } \\
\text { s at } \\
\text { theatres }\end{array}$ & $\begin{array}{c}\text { Numbe } \\
\text { r of } \\
\text { theatre } \\
\mathrm{s}\end{array}$ \\
\hline Györ & 12 & 55 & 71.596 & 660 & 0.005 & 163.934 & 2 \\
\hline $\begin{array}{c}\text { Veszpré } \\
\mathrm{m}\end{array}$ & 3 & 37 & 90.869 & 402 & 0.007 & 75.480 & 2 \\
\hline $\begin{array}{c}\text { Debrece } \\
\mathrm{n}\end{array}$ & 7 & 36 & $\begin{array}{c}162.57 \\
3\end{array}$ & 775 & 0.004 & 115.148 & 2 \\
\hline
\end{tabular}

Source: own edition based on Central Statistics Office figures 
On the basis of Tab. 4 it is obvious that Györ stands first as far as museums are concerned, the city has 12 institutions of historic heritage. The number of museums with art exhibitions is 7 in Debrecen and 3 in Veszprém. The number of exhibitions organised in Györ was the highest in 2015, the museums in the city set up 55 art shows, the number of exhibitions that took place in Veszprém was 36, in Debrecen this number was 36. It is interesting to point out that even though Györ has the greatest number of museums the number of visitors of museums is the lowest compared to the other cities examined in the present study, slightly more than 70.000 people wanted to see the art exhibitions. A low number of museums can be found in Veszprém, however, they attracted 90.000 visitors and in 2015 and Debrecen could record an exceedingly high number of visitors in their museums, approximately 162.000 people. To change over to the sphere of theatres, it can be stated that Debrecen and Györ likewise hosted 600-700 performances in their theatres and Veszprém organised 402 theatre performances during the examined period, which is a slightly lower number. Györ is standing out compared to the other cities discussed as far as the number of visitors of the theatres is concerned: the spectators purchased 164.000 theatre tickets, which number amounts to 50.000 more than in Debrecen and it is 90.000 more compared to the figures of Veszprém. The number of theatres is 2 in the case of both cities.

Finally, in the case of the number of performance of theatres, the per capita value was also taken into account. The value of this indicator in case of Veszprém is the best, the second best number can found in the case of Györ, while Debrecen lags behind the former two cities in terms of this indicator. However, we continue to emphasize that in the case of the European Capital of Culture project, it is not the needs of the local population that need to be met as much as possible, but those of millions of visitors, who will come in the year of the ECoC project.

\section{TOURISM CAPACITY}

In terms of the tourism potential of our examined cities, we first compare the accommodation places of commercial accommodation establishments. Our data source was the TEIR ${ }^{11}$ database, however, the data of the last five years were missing, so we took the 2008 global economic crisis as a starting point, compared to which year we show the development of the values in Fig. 2. The data were given per 100 thousand inhabitants. Based on the figure (below), it can be seen that we can establish the following order: Debrecen, Györ, Veszprém, if the accommodation capacities are compared on the basis

\footnotetext{
${ }^{11}$ National Spatial Development and Spatial Planning Information System of Hungary
} 
of the latest available data. At the same time, the chart also shows that capacities have changed from year to year, in any case showing a significant increase compared to the year of the crisis.

Figure 2 Number of beds in commercial accommodation per 100.000 inhabitants

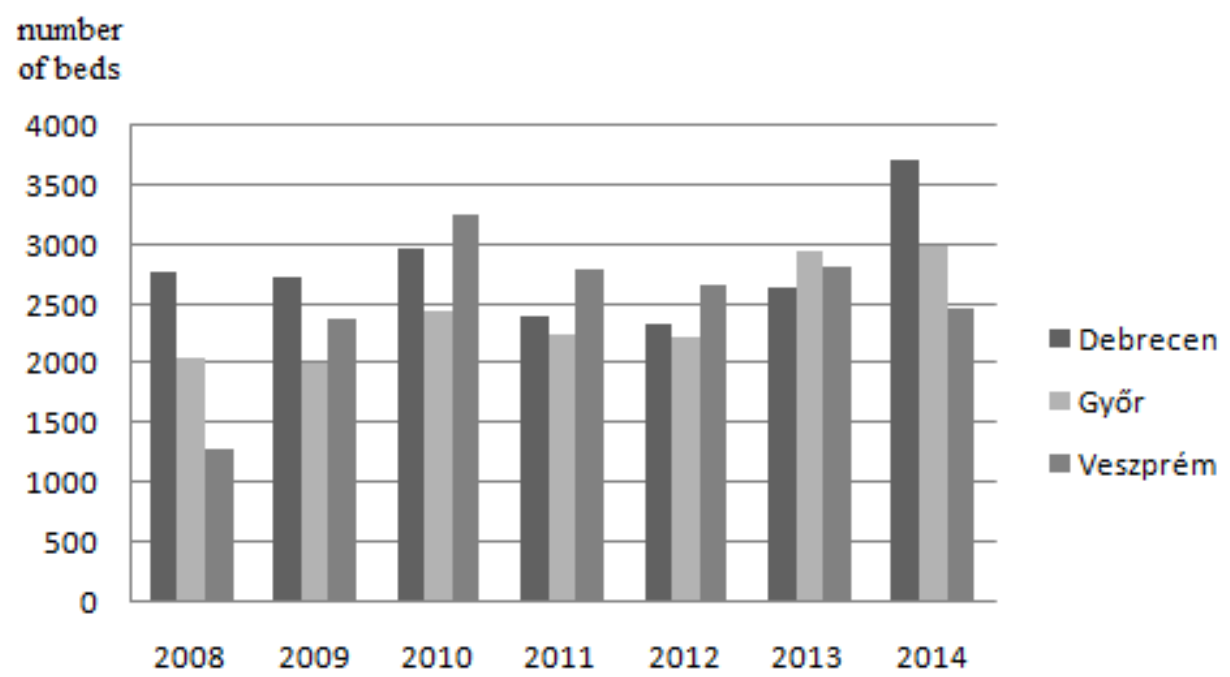

Source: own editing based on database of TEIR

The capacities of this accommodation are discussed in more detail below thanks to the data provided in the ECoC applications of the three examined cities.

Table 5 Accommodation facilities in the candidate cities

\begin{tabular}{|c|c|c|c|c|c|c|c|c|}
\hline \multicolumn{3}{|c|}{ Győr } & \multicolumn{3}{|c|}{ Veszprém } & \multicolumn{3}{|c|}{ Debrecen } \\
\hline Category & $\begin{array}{c}\text { Places of } \\
\text { accommodation }\end{array}$ & $\begin{array}{c}\text { Capacit } \\
\text { y }\end{array}$ & Category & $\begin{array}{c}\text { Veszpré } \\
\mathrm{m}\end{array}$ & Region & Category & $\begin{array}{c}\text { Volum } \\
\mathrm{e}\end{array}$ & $\begin{array}{l}\text { Number } \\
\text { of beds }\end{array}$ \\
\hline $\begin{array}{l}4 \text { star } \\
\text { hotel }\end{array}$ & 8 & 678 & 4 star hotel & 161 & 3.500 & $\begin{array}{l}5 \text { star } \\
\text { hotel }\end{array}$ & 1 & $\begin{array}{c}\text { no data } \\
\text { (n. d.) }\end{array}$ \\
\hline $\begin{array}{l}3 \text { star } \\
\text { hotel }\end{array}$ & 19 & 1.387 & 3 star hotel & 70 & 2.256 & $\begin{array}{l}4 \text { star } \\
\text { hotel }\end{array}$ & 8 & n. d. \\
\hline $\begin{array}{l}\text { Guest- } \\
\text { house }\end{array}$ & 23 & 585 & Guest-house & 365 & 1.150 & $\begin{array}{l}3 \text { star } \\
\text { hotel }\end{array}$ & 6 & n. d. \\
\hline Other & 42 & 3.335 & $\begin{array}{c}\text { Places of } \\
\text { private } \\
\text { accomodatio } \\
n\end{array}$ & 150 & 29.653 & $\begin{array}{c}\text { Other } \\
\text { commerc } \\
\text { ial places } \\
\text { of } \\
\text { accomod } \\
\text { ation }\end{array}$ & 32 & n. d. \\
\hline & & & Hostel & \multicolumn{2}{|c|}{1.606} & private & 150 & n.d. \\
\hline & & & Camp site & \multicolumn{2}{|c|}{17} & & & \\
\hline & & & $\begin{array}{c}\text { Couchsurfin } \\
\mathrm{g}\end{array}$ & 537 & & & & \\
\hline & & & Airbnb & \multicolumn{2}{|c|}{300} & & & \\
\hline & & & Other & \multicolumn{2}{|c|}{ no data } & & & \\
\hline Total & 92 & 5.985 & Total & 1.650 & 56.300 & Total & 197 & 7.289 \\
\hline
\end{tabular}

Source: own editing based on the figures of the application documents 
The top line of Tab. 5 includes accommodation facilities and capacities of the cities. It is unambiguous that Debrecen would be able to sleep the highest number of guests in the ECOC year, Györ stands second in this respect and Veszprém is the third city in the ranking. In the application dossier the city of Veszprém supplied information on the accommodation capacity of its region as well, not by accident, the city is planning the ECOC project in regional dimension, hand in hand with the Balaton area. At the same time, for the purposes of our investigation, the accommodation capacity in the cities were taken into account. Debrecen did not supply information on the number of places of accommodation and provided only totaled data in the application dossier, which means it was not specified in the document how the 7.300 beds were distributed among the different types of places of accommodation.

Table 6 The number of overnight staysin the candidte cities in 2017 (pers.)

\begin{tabular}{|c|c|c|}
\hline Győr & Veszprém & Debrecen \\
\hline 417.491 & 219.500 & 374.016 \\
\hline
\end{tabular}

Source: own editing based on the figures of the application documents

Tab. 6 shows the number of overnight stays in the course of years. The application dossier of Győr contains annual data, Veszprém is supposed to have supplied the data of the last year available and Debrecen did not at all provide any data regarding the change of the indicator. It is however unambiguously shown in the table that Györ has multiple values compared to Veszprém.

Figure 3 Number of guest nights in commercial accommodation establishments per 100,000 inhabitants

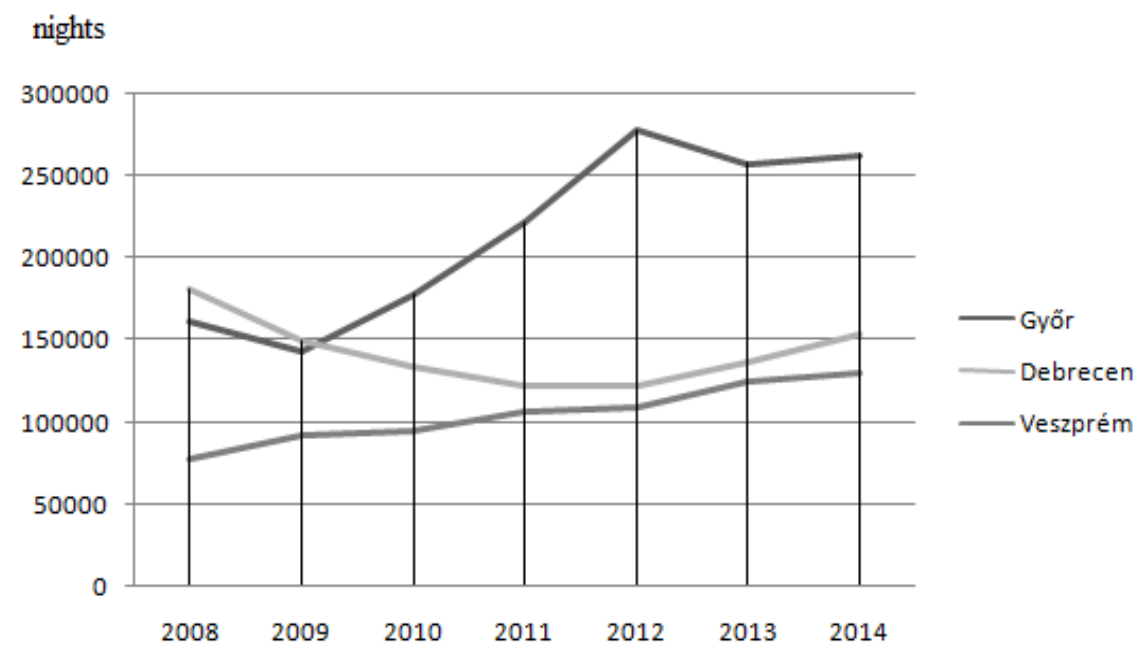

Source: own editing based database of TEIR 
In Fig. 3, we wanted to show the change in the number of guest nights for the three examined cities. Data on the last five years were also not available in the TEIR database in terms of this indicator, so we also took as a starting point the 2008 global economic crisis. In Figure we can see the change of the number of guest nights in commercial accommodation in Györ, Debrecen and Veszprém. It can be clearly seen in the figure that Győr has the highest numbers per 100 thousand inhabitants. From the starting year, there is an increase in the terms of this indicator. Debrecen shows a rather declining trend with regard to the examined indicator, but from 2011 onwards Debrecen could experience a slow increase. Finally, the city of Veszprém has the lowest value of the indicator, but at the same time the city can boast a continuous, steady upward trend.

\section{FINANCING CAPACITY}

Tab. 7 shows the scale of the cultural budget of the applicant cities. In fact, an index number is also included in the table that compares the budget of the cultural region with the total budget of the city in the given years. The relevant figure for us is the latter ratio, as we cannot expect from Veszprém, with a population of 60.000 , to spend the same amount on culture as the other two regional centers. Based on the figures, it is evident that Györ has the largest scale of cultural funding and there is a significant volume of cultural budget available for Debrecen as well. Veszprém, being a smaller-size settlement, spends less on the maintenance and promotion of culture compared to the former two cities. In the case of all the three cities the increasing tendency can be observed together with the occurrence of a smaller scale recession at certain points and the candidate cities are making efforts to promote culture on a greater scale.

Table 7 The cultural budget of the candidate cities in the course of the years

\begin{tabular}{|c|c|c|c|c|c|c|}
\hline & \multicolumn{2}{|c|}{ Györ } & \multicolumn{2}{c|}{ Veszprém } & \multicolumn{2}{c|}{ Debrecen } \\
\hline Year & $\begin{array}{c}\text { Cultural } \\
\text { budget } \\
\text { (Euro) }\end{array}$ & $\begin{array}{c}\text { Percentage } \\
\text { of total city } \\
\text { budget }\end{array}$ & $\begin{array}{c}\text { Cultural } \\
\text { budget } \\
\text { (Euro) }\end{array}$ & $\begin{array}{c}\text { Percentage of } \\
\text { total city } \\
\text { budget }\end{array}$ & $\begin{array}{c}\text { Cultural } \\
\text { budget } \\
\text { (Euro) }\end{array}$ & $\begin{array}{c}\text { Percentage of } \\
\text { total city } \\
\text { budget }\end{array}$ \\
\hline 2014 & 20.203 .949 & $11.5 \%$ & 4.737 .181 & $9 \%$ & 12.598 .990 & $10.06 \%$ \\
\hline 2015 & 19.644 .547 & $12.6 \%$ & 4.886 .031 & $10.9 \%$ & 15.351 .325 & $12.74 \%$ \\
\hline 2016 & 20.838 .865 & $11.4 \%$ & 4.704 .581 & $12 \%$ & 16.862 .503 & $15.19 \%$ \\
\hline 2017 & 19.355 .809 & $9.0 \%$ & 6.912 .192 & $15.6 \%$ & 18.260 .173 & $13.88 \%$ \\
\hline
\end{tabular}

Source: own editing based on the figures of the application documents

Returning to the ratios, it can be seen that regarding earlier years Veszprém provided a particularly high $15.6 \%$ rate for year 2017. Only Debrecen founded culture in 2016 with such a high rate and at the same time Debrecen also produced a high rate of $13.88 \%$ in 
2017. Index numbers of approximately 12\% appeared regarding year 2015 in the case of Györ and in the case of the budget of Debrecen, and in the case of Veszprém in 2016.

In their tender documents all the three cities committed themselves to increasing this rate to $15 \%$ in the future five-year-period, which ambition indicates the cultural strategies of the cities and their commitment to promote culture as well as their first steps towards cultural economy.

The cultural budgets per capita of the three cities are shown in Fig. 4. It is an outstanding fact that the cultural budget of Györ surpasses the city of Veszprém and Debrecen as well. The differences between the values are the consequence of the fact that the city can manage a higher scale total budget and this is also demonstrated by the $9 \%$ index number of year 2017 (Tab. 7). This value shows that although this year the proportion of expenditures of Győr spent on financing culture was lower in the total city budget compared to the other two cities, the degree of the amount spent on culture was still higher than the expenditures of Veszprém and Debrecen. Consequently, the scheme of financing policy and the potentials of real economy must be delimited, all the candidates have plans, but there are different kinds of resources available for the three cities.

Figure 4 Cultural budgets per capita of the applicant cities in the course of the years

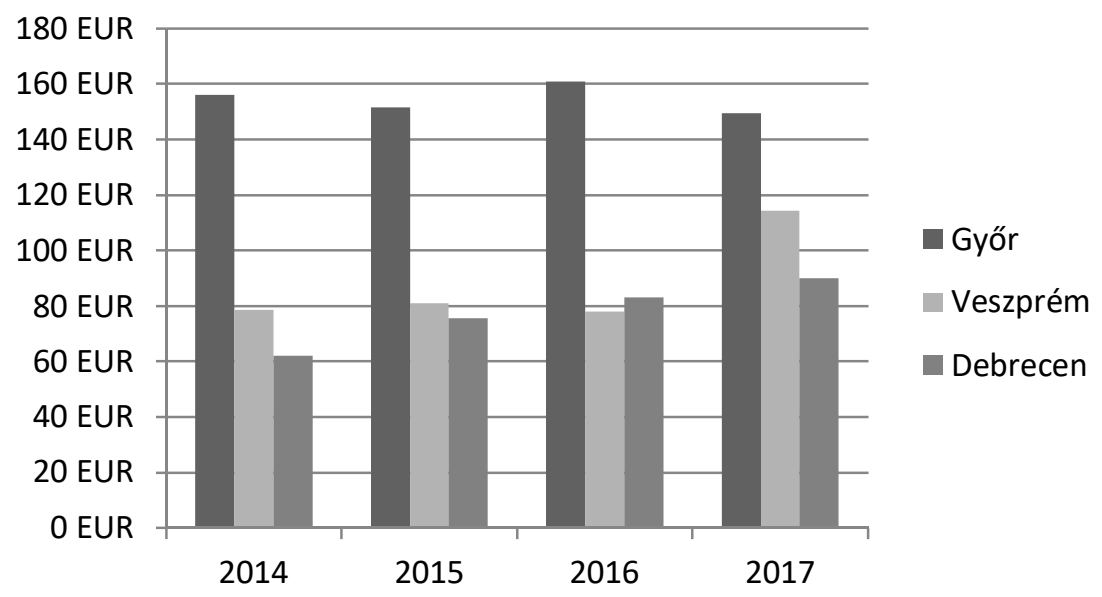

Source: own edition based on the application documents

High-quality cultural environment is required by the ECOC project, as a result, candidate cities feel urged to bring about significant investments and developments in the cultural sphere. The three cities examined in the present study are planning numerous investments in the future five years, certain investments directly serve to develop the conditions of the ECOC project, certain investments, however, contribute to the success of the project in an indirect way. Relevant data is shown by Tab. 8 . 
Table 8 Number of investments in the candidate cities

\begin{tabular}{|c|c|c|}
\hline \multicolumn{1}{|c|}{ Györ } & $\begin{array}{c}\text { Investments directly } \\
\text { connected to the ECOC } \\
\text { project }\end{array}$ & Investments indirectly connected to the ECOC project \\
\hline $\begin{array}{l}\text { Number of } \\
\text { investments }\end{array}$ & 18 & 10 \\
\hline Veszprém & $\begin{array}{c}\text { Projects in process and } \\
\text { investments in sites already } \\
\text { set up }\end{array}$ & Investments directly connected to the ECOC project \\
\hline $\begin{array}{l}\text { Number of } \\
\text { investments }\end{array}$ & 7 & 6 \\
\hline \multicolumn{1}{|c|}{ Debrecen } & $\begin{array}{c}\text { Investments directly } \\
\text { connected to the ECOC } \\
\text { project }\end{array}$ & Investments indirectly connected to the ECOC project \\
\hline $\begin{array}{l}\text { Number of } \\
\text { investments }\end{array}$ & 11 & 10 \\
\hline
\end{tabular}

Source: own edition based on the application documents

Györ is endeavoring to carry out 28 investments because of the ECC project and in order to develop the field of culture. The city is planning to carry out 10 investments in direct connection with the project discussed, and finance them by the accessible resources of the Modern Cities Programme, the Local Government and the European Union. Concerning direct projects and investments Veszprém has had smaller scale plans, which include the development of several already existing institutions. Indirect projects are also estimated and they include new sites as well.

Debrecen can be considered exactly the opposite of Veszprém in this respect, the city is planning a great number of direct investments. These investments are, with the exception of certain examples, projects of infrastructure development. Moreover, significant number of indirect projects are being planned in Debrecen with the help of financial resources similar to Győr.

Table 9 The proportion of operational expenses in the budget of the candidate cities

\begin{tabular}{|l|l|l|l|l|l|l|l|l|}
\hline \multicolumn{2}{|c|}{ Győr } & \multicolumn{3}{c|}{ Veszprém } & \multicolumn{3}{c|}{ Debrecen } \\
\hline $\begin{array}{l}\text { Operation costs } \\
\text { (Euro) }\end{array}$ & $\begin{array}{l}\text { Public } \\
\text { sector }\end{array}$ & $\begin{array}{l}\text { Private } \\
\text { sector }\end{array}$ & $\begin{array}{l}\text { Operation costs } \\
\text { (Euro) }\end{array}$ & $\begin{array}{l}\text { Public } \\
\text { sector }\end{array}$ & $\begin{array}{l}\text { Private } \\
\text { sector }\end{array}$ & $\begin{array}{l}\text { Operation costs } \\
\text { (Euro) }\end{array}$ & $\begin{array}{l}\text { Public } \\
\text { sector }\end{array}$ & $\begin{array}{l}\text { Private } \\
\text { sector }\end{array}$ \\
\hline 25.012 .148 & $89.7 \%$ & $10.3 \%$ & 31.700 .000 & $88 \%$ & $12 \%$ & 40.320 .000 & $90.1 \%$ & $9.9 \%$ \\
\hline \multicolumn{7}{|c|}{ Division of public sector resources (euro) } \\
\hline $\begin{array}{l}\text { National } \\
\text { government }\end{array}$ & 8.012 .821 & $\begin{array}{l}\text { National } \\
\text { government }\end{array}$ & 12.700 .000 & $\begin{array}{l}\text { National } \\
\text { government }\end{array}$ & 20.000 .000 \\
\hline City & 9.615 .384 & City & 11.160 .000 & City & 11.820 .000 \\
\hline Region & 0 & Region & 2.790 .000 & Region & 0 \\
\hline EU & 4.807 .692 & EU & 1.250 .000 & EU & 1.500 .000 \\
\hline Others & 0 & Others & 0 & Others & 3.000 .000 \\
\hline
\end{tabular}

Source: own edition based on the tender documents 
Tab. 9 shows the budget planning of the ECOC project, the amount of revenue that covers the costs and the distribution of the resources. All the three cities aim to finance the operational costs of the project mainly from public resources with a proportion of about $9-10 \%$. The city of Veszprém is inclined to rely more on the private sector in this regard and hopes that approximately $12 \%$ will be collected from private contribution. In a detailed examination of the distribution of resources it becomes clear that Györ is expecting to get approximately 8 million Euros from the National Government, while Veszprém is expecting 12.7 million Euros, a considerably greater amount and Debrecen hopes for 20 million Euros. At the same time, Veszprém is bolder in the city level in its project financing plan compared to Györ. Veszprém is inclined to spend more than EUR 11 million for this purpose and also trusts that its region will also contribute to the costs with nearly EUR 3 million. Debrecen also intends to launch the project with similar ambition and the city would spend an amount of EURO 11.8 million as a charge on its own budget. Among the financial resources expected from the European Union, the targeted amount is very high in the case of Györ, the city expects nearly EUR 5 million in EU funding for the project, however, the other two cities defined the financial item as an amount of EURO 1-1.5 million.

All in all, the budget plans can be described by the features that the Gyor plan is the most reasonable, the Veszprém plan is of a greater volume and the Debrecen plan can be considered the largest scale.

Figure 5 ECoC operational expenses per capita of the candidate cities

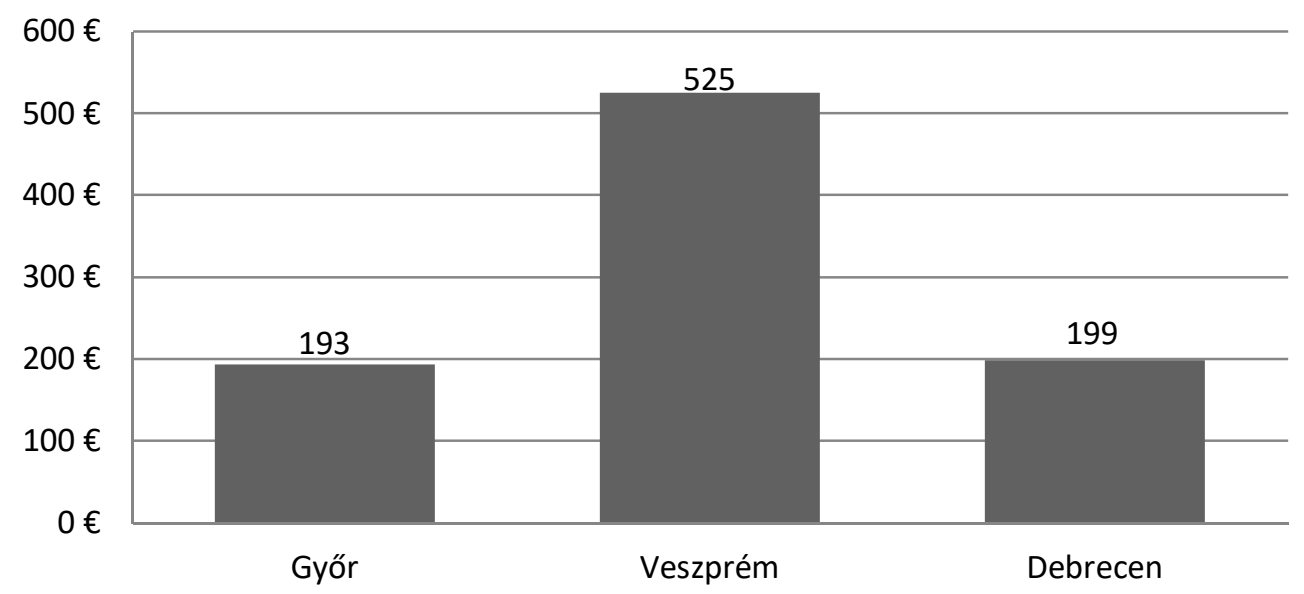

Source: own edition based on the application documents 
Fig. 5 shows the visually represented values of the budget plans per capita discussed above, which properly illustrates that Veszprém in proportion to its population is considering a largest project and would be ready to spend more than double of the amount on the project compared to the city of Györ and Debrecen. As a matter of course, the resources for covering the operating costs discussed above would not be transmitted to the account of the winning city in one amount, but in an annual schedule distributed in a six-year period.

\section{DISCUSSION}

On the basis of the analytical framework outlined in the introduction of this study the following Tab. 10 provides a summary of the research. In the case of certain indicators, the city showing the highest quantitative result was awarded 1 point, however, 3 points were awarded to the city with the lowest result. Consequently, the lower the points of a city are, the better results they can take pride in.

Table 10 Results of the research

\begin{tabular}{|l|l|l|l|l|}
\hline $\begin{array}{l}\text { Research } \\
\text { criteria }\end{array}$ & Indicators & Györ & Veszprém & Debrecen \\
\hline $\begin{array}{l}\text { Cultural } \\
\text { capacity }\end{array}$ & I1. Number of institutions of public education & 3 & 2 & 1 \\
\hline & I2. Number of cultural programmes & 2 & 3 & 1 \\
\hline & I3. Number of participants in cultural programmes & 2 & 3 & 1 \\
\hline & I4. Number of institutions of historic value & 1 & 3 & 2 \\
\hline & I5. Number of museum exhibitions & 1 & 2 & 3 \\
\hline & I6. Number of museum visitors & 3 & 2 & 1 \\
\hline & I7. Number of theatre performances & 2 & 3 & 1 \\
\hline & I8 Number of spectators at the theatres & 1 & 3 & 2 \\
\hline & sum & 15 & 21 & 12 \\
\hline & & & & \\
\hline $\begin{array}{l}\text { Tourism } \\
\text { potentials }\end{array}$ & I9. Number of accommodation capacities & 2 & 3 & 1 \\
\hline & I10. Number of overnight stays & 1 & 3 & 2 \\
\hline & sum & 3 & 6 & 3 \\
\hline & & & & \\
\hline $\begin{array}{l}\text { Financial } \\
\text { capacities }\end{array}$ & I11. Volume of cultural budget & 1 & 3 & 2 \\
\hline & & & & 2 \\
\hline & $\begin{array}{l}\text { I12. The proportion of cultural budget relative to the } \\
\text { total budget }\end{array}$ & 2 & 1 & 3 \\
\hline & I13. Number of planned investments & 1 & 3 & 2 \\
\hline & I14. Planned amount of operating costs & 3 & 2 & 1 \\
\hline & sum & 7 & 9 & 8 \\
\hline
\end{tabular}


It can be seen that Debrecen has achieved the best result in terms of cultural capacity, Györ closely follows and Veszprém has come third. It is worth of attention that in the case of certain indicators only Győr and Debrecen come in the first places and Veszprém did not prove to be the best in any research criteria. In terms of tourism potentials Györ and Debrecen have come first with similar points, according to both indicators Veszprém has proved to be the weakest. As a result of financial capacities Győr has taken the lead, followed by Debrecen and Veszprém. In fact, Veszprém was only able to take the lead in terms of one indicator which is the proportion of the city budget spent on the cultural sphere. This can obviously be explained by the size of the city and the volume of its budget as well.

\section{CONCLUSION}

The aim of the study was to evaluate the performance of Hungarian cities applying for the 2023 $\mathrm{ECoC}$ on the basis of specific indicators. The order of strength established on the basis of the selected cultural, tourism and financial indicators. The order shows the relative performance of the three Hungarian cities that got into the second round of the selection process for ECoC title. Based on the analysis, it can be said that based on the selected indicators, the two Hungarian cities, Györ and Debrecen produced better results than Veszprém in practically all cases.

All in all, it can be seen in Table 10 that based on the examined indicators the two major cities, Györ and Debrecen finished shoulder to shoulder according to the research and Veszprém clearly got the weakest result. At the same time, Veszprém was appointed the title of European Capital of Culture by the International Jury on 14th December 2018. This also shows that the selection was, of course, not only based on quantitative indicators, but also on other factors that cannot or only difficult to measure (creative elements of each application, professional / political lobby, regional development considerations, etc.). The reason for the decision could have been also the fact that, apart from the success of the possible objective criteria listed in the previous chapter, the Jury considered the award to be a good opportunity for the small city with weak hard indicators to develop and make a real breakthrough.

\section{REFERENCES}

Balsas, C. J. L. (2004). City centre regeneration in the context of the 2001 European capital of culture in Porto, Portugal, Local Economy, 19(4), 396-410.

Boland, P. (2010). 'Capital of Culture-you must be having a laugh!' Challenging the official rhetoric of Liverpool as the 2008 European cultural capital, Social \& Cultural Geography, 11(7), 627-645, DOI: 10.1080/14649365.2010.508562

Campbell, P. (2011). Creative industries in a European Capital of Culture, International Journal of Cultural Policy, 17(5), 510-522, DOI: 10.1080/10286632.2010.543461 
Cohen - Hattab, \& K. Shoval, N.(2007). Tourism development and cultural conflict: the case of 'Nazareth 2000', Social \& Cultural Geography, 8(5), 701-717, DOI: $10.1080 / 14649360701633220$

Deuze, M. (2009). Convergence Culture and Media Work. In: Holt, J., \& Perren, A. (eds.): Media Industries - History, Theory, and Method. Wiley-Blackwell, Malden, MA, 14456. Dimension. Social Forces, 85(4), 1465-1482.

Enyedi, Gy. (2005). A városok kulturális gazdasága. [Cultural economy of cities.] In: Enyedi Gy., \& Keresztély K. (szerk.): A magyar városok kulturális gazdasága. [Cultural economy of Hungarian cities.] MTA Társadalomkutató Központ, Budapest. 13-27.

Európai Bizottság [European Commission] (2010). Zöld könyv a kulturális és kreatív iparágak potenciáljának felszabadításáról. [GREEN PAPER. Unlocking the potential of cultural and creative industries]

Evans, G. L. (2009). Creative cities, creative spaces and urban policy, Urban Studies, 46(5/6), $1003-1040$.

Fekete, D. (2018a). Economic Development and Economic Governance Through the Example of the City of Györ. Deturope, 10(1), 97-115.

Fekete, D. (2018b). Latest Results of the Győr Cooperation Model. Polgári Szemle, 14, 195209.

Garcia, B. (2004). Cultural policy and urban regeneration in Western European cities. Local Economy, 19(4), 312-326.

Gibson, C. (2003). Cultures at work: Why 'culture' matters in research on the 'cultural' industries, Social \& Cultural Geography, 4(2), 201-215, DOI: $10.1080 / 14649360309059$

Haarich, S., \& Plaza, B. (2010). "Das Guggenheim-Museum von Bilbao als Symbol für erfolgreichen Wandel - Legende und Wirklichkeit" in: Altrock, U., Huning, S., Kuder, T., Nuissl, H. \& Peters, D. (eds.): Symbolische Orte. Planerische (De) Konstruktionen. Reihe Planungs rundschau, 19, Berlin. 1-17.

Hojnik, B., \& Rebernik, M. (2014). Insight into creative and cultural industries in Slovenia. Business Management Dynamics, 3(9), 10-15.

KSH Agglomerációk, település-együttesek 2014; Magyarország közigazgatási helynévkönyve, KSH, 2015. [Agglomerations. Administrative toponymy of Hungary.]

Morvay, Sz., Rechnitzer, J., \& Fekete, D. (2020). Európa Kulturális Fővárosai Kelet-KözépEurópában. [European Capitals of Culture in Central and Eastern Europe.] Tér és társadalom, 34(1), 119-139.

Ooi, C.S, Hakanson, L., \& Lacava, L. (2014). Poetics and Politics of the European Capital of Culture Project. Procedia - Social and Behavioral Sciences, 148., 420-427.

Palmer-Rae (2004). European Cities and Capitals of Culture (Brussels: Palmer-Rae Associates).

Richards, G., \& Palmer, R. (2010). Eventful Cities: Cultural Management and Urban Revitalization (Amsterdam: Butterworth-Heinemann).

Szirmai, V. (1996). Közép-európai új városok az átmenetben. [Central European cities in the transition period.] Szociológiai szemle. 3-4., 181-205.

Throsby, D. (2010). The economics of cultural policy. Cambridge University Press. Cambridge. 277.

UNCTAD (2010). The Creative Economy Report. http://www.unctad.org/creativeeconomy

Wiesel, I. (2018). Producing and appropriating neighbourhood prestige: cultural capital in Australia's elite suburbs, Social \& Cultural Geography, DOI: $10.1080 / 14649365.2018 .1541249$ 